\title{
2-Fluoropropionyl-labeled Pegylated Dimeric RGD Peptide
}

National Cancer Institute

\section{Source}

National Cancer Institute. 2-Fluoropropionyl-labeled Pegylated Dimeric RGD Peptide. NCI

Thesaurus. Code C97336.

A radiopharmaceutical agent comprised of a pegylated dimeric arg inine-glycine-aspartic acid (RGD)-based peptide labeled with 2-fluoropropionyl, with potential alphaVbeta3 integrin imaging activity upon positron emission topography (PET). The RGD moiety of 2-fluoropropionyl-labeled pegylated dimeric RGD peptide targets and binds to alphaVbeta3 integrin. Upon PET imaging, alphaVbeta3 integrin-expressing tumor cells can be visualized and expression levels can be quantified. Compared to other fluorine F 18 labeled RGD-containing peptides, this agent shows increased affinity to alphaVbeta3 integrin, enhanced tumor uptake as well as improved pharmacokinetics. alphaVbeta3 integ rin, overexpressed on certain tumor cells and tumor endothelial cells, plays a key role in angiogenesis, tumor proliferation and survival. 